\section{GUNSHOT WOUND OF THE CHEST AND INJURY 'TO THE SPINE}

\section{WITII SPECIAI REFTRENCE TO PROGNOSIS}

\section{R. T. FERGUSON, M.D.} GAFFNEY, s. c.

I report this case to furnish some jica of the prognosis to be made in cases involving injury to the spine. The literature on prognosis in such injuries is very incomplete.

History.-The patient, a colored man, aged 21, single, laborer in a railway eamp, was shot July 18, 1909 at dose range with a 38 -caliber revolver, the ball entering the eighth interspace on the right side one inch to the right of the mammillary line, passing downward and backward and emerg. ing through the eleventh interspace behind in the mid-senp. ular line $23 / 4$ inches to the left of the spinous process of the eleventh dorsal vertebra. The man was hanled 4 miles in a wagon and 12 on train with no dressing on either wound.

Examinations.-The pulse was 130, the temperature 102, respirations 30, paralysis of the left thigh and leg was complete. There was retention of urine and paralysis of rectum with involuntary evacuations; loss of all sensation in the left thigh and leg supplied by the musculocutaneous, external saphenous, anterior tibial, extorhal and intermal plantar, and internal calcanen and the lower part of the leg that is supplied by the lateral cutaneous and internal saphenous nerves.

Course of Case--The patient had to be cuthetertzed for iwo weeks, after which there was involuntary urination as we!l as defecation for six montlis; since that time he has improved steadily until now (twelve and a half months after injury) he can control bowels perfectly and retain his urine four to five hours. A bed-sore six inches in diameter developed over the sacral region and smaller ones over both hips, which caused a considerable smount of trouble.

'Temperature ranged between 101 and $1043 / 5$ for a month, after which time it became normal. After two months the patient could move the toes slightly, then the foot, knee and thigh; and six montlos after the injury he could move the entire leg a small distauce in every direction. August 9, 1910 he is walking around quite well without the use of his crutch and gives every indication of an early and complete recovery. The injury to the spinal cord appeared to be limited to the dircet pyramidal tract and antero-lateral column in the left side of the cord.

800 Limestone Strect.

Bilateral Herpes Zoster.-Dr. Lester C. Diddy, Oswego, Ill., writes: Reading the article in Tre Joursat (July 30 , p. 372), by Drs. Varney and Jamiason boought to mind a similar case, which occurred in my pratice recently, of which the following is a brief report: Mrs. S., housewife, nged 54, American, whose family history is negative, as far as anything bearing on the present condition is concerned, had the ordinary diseases of childhood, since which time she has bren healthy. There is no history of injury at the site of eruption. Pain of Beuralgic aharacter appeared several days before the lesions, which were typical of herpes zoster. 'Tluey first apprared on the left side. in the dorsal region nenr the midnxillary line, and gradually extended over nearly the entire left half of the chest and abdomen anteriorly and posteriorly. Lesions appenred on the right lanlf of chest and nblomen and extended until they met those on the left side, rompletely girdling the patient. The lesions berame very extensive and caused no little annoynnce. They extended upward to the second rib in front and to the scapula behind, downward to the groin on the right side, and about half way down the left thigh, and down the back as far ns the buttoeks. The inner surface of the left arm was also aflected, nearly to the: wrist.

\section{CASE OF A SPOOL EMBEDDED IN THE CERVIX U'IERI}

\section{A. P. STONER, M.D.}

Instructor in Surgery Madical Depmetment, Inake University. At. tending Sugeon Mercy IIospltal.

\section{DUS MOJNIS, JOWA}

Hislony.—S. T., anged 16, colored, entered my service at the surgical dispensary of Drake University, July 14, with a his. tory of pelvic trouble of some years stunding. She menstruated at 13 for 5 sncessive periods, nfter which time the period ceased altogether.

Loaminalion.-Her general condition and appearance was good and she was of avernge intelligence. On investigation the underclothing was found to be siturated with urine and the vulvar region was excoriated. A vegetative growth of small size and of a reddish lue, surrounded the mentus, and urine was trickling from the vagina. The examining finger came in contact with a foreign body in the vagina, which proved to be a wooden spool. Further examination showed that one end of the spool which measured about 5 contimeters in length, was securely embedded in the cervix. The free end was grasped with a pair of forceps and an attempt made to extract it, but this effort created great pain, and chloro. form was administered. A more complete examination was

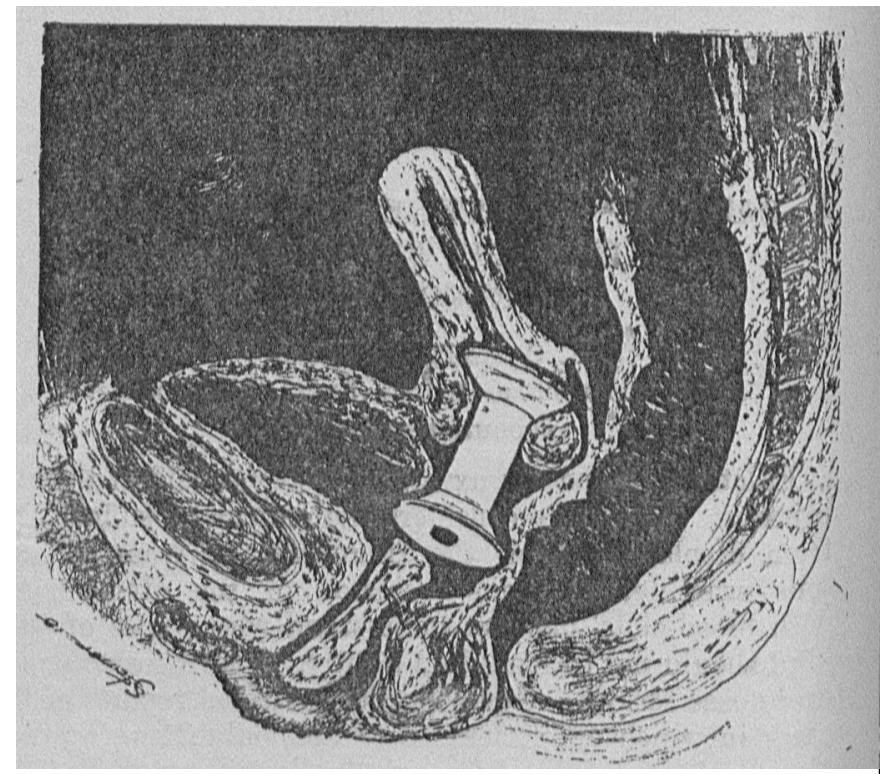

Drawing to sliow position of spool befole removal, whth infantile nterus aud flstilous tirets rrom bladder and uterus into vagina.

then made. The uterus was retroverted and its body atro. phivel. The cervix held the spool tightly, about its middlo third. One edge of the upper end of the spool through pressure necrosis, had worked its way through the uterine tissue baek into the vagina.

Ireatment.-As it was impossible to extract it forcibly or to dilate the eanal the cervicul tissue was divided at this point and the spool relensed.

Remarls.-The free end for the spool was covered with (alculous salts and its upper edge latd protruded into tho basc of the bladder, creating a vesico-vaginal fistula, through which the index finger could be frenly pussed. The girl denied all knowledge of the presence of a foreign body in the vag ina, but stated that when she was about 8 years old lier mother, who was very unkind to her, had placed something in the vaginal canal which gave her great pain and eaused hemorrage for a fow days. She has lad more or less discharge ever since, she rlilims, but it wats not uutil 8 or $\theta$ months ago that the urine bogan to pass through the vagina.

The lengits of time the spool had been in the uterus, and the inanner jn which it lad become embedded 
therein are of interest. Conception and abertion wcre denied, and excluding the latter, the only plinsible solution seems to be, that the spool was inserted by the patient into the vagina, and as she was probably unable to remove it, the upper edge of the spool by constant pressure against the external os produced sufficient dilatation to allow the spool to pass into the cervical canal. 'J'his new position assumed by the spool then caused retroversion of the uterus, while its presence interfered with the nutrition and growth of the organ. The opposite end of the spool also assumed a more intimate contact with the bladder wall, causing pressure necrosis and a fistula. The walls of the vagina were found to be thickened, very nodular and much reduced in depth.

\section{CONCUSSION OF THE BRAIN}

\section{ALFRED REGINALD ALILEN, M.D.} Lecturer on Newrologic Inlectrothernentics, Instructor in Neu
rology and in Nemo-I'athology at the University of Pennsylvania

\section{PIILADELIIIA}

In this day and generation a justification is desirable when a single case is reporterl. 'This is particularly in order when the case is one of cerebral concussion. Nevertheless, on account of the extraordinary symptom-complex and course of the case in cuestion, J offer no apology for its presentation.

History.-August 6, 1010, IJ. D., male, aged $6 \frac{1}{2}$, weight 49 pounds, in robust health, fell while ruming on the porch, striking the left side of his hend. The time of the accident was about $4 \mathrm{p}$. m. Jutging from the position of the echymosis, which was very sliglit, the point of impact must have been about $4 \mathrm{~cm}$. above and $2 \mathrm{~cm}$. behind the external canthus of the left eye.

I saw the child within ten minutes of the accident. The nurse said that after he fell he got upon his feet immediately, crying lustily. He was very pale, and the nurse thinking that he was more scared then lurt, sought to pacify him by walking. He had not gone far before lie said: "I can't see anything but sky."

Examination.- My examination revealed the following condition: Total blindness in both eyes for both form and lights. A lighted eandle held $25 \mathrm{~cm}$. from his eyes in a darkened room gave no visual impression of light. The iricles reacted to light. All extraocular movements were perfectly normal. The hearing in each ear was normal. The tongue was protruded in the median line. There was no involvement of the facial muscles, and the elevation of the soft palate was normal and symmetrical. The movements of the upper and lower extremities were normal in all directions. The reflexes of the upper extremities were normal and no spasticity was present. Both knee jerks were greatly exaggerated, and although there Was no ankle clonus present, yet the sudden flexion of the foot at the ankle provoked one quick reflex extension movement. Passive movement of the lower extremities demonstrated a very decided degree of spasticity. Normal plantin reflex was present on right, but a well marked Babinski ular, was elicited on the left. The pulse was full but irregwas, and at the rate of 68 to 72 per minute. The breathing was deep and signling in character, and at the rate of 16 per mente. He answered questions readily, and showed great mental distress because he was afraid he would never see again. After the examination he quickly went to sleep. He sition be aroused from this sleep, and showed no predispostill to lic on either side. During this sleep the breatling I maintained the deep simhing character.

frist, made my second exnmination about one hour after the present which time all the symptoms as above recorded were candle with the exception thint on testing the eyes with the Was plac said that it seemed $n$ little lighter when the candle was placed $25 \mathrm{~cm}$. in front of his eyes. The Babinski reflex on the left at this examination was pronounced. In a half hour from this time he called a lighted enndle a lighted mateh. In another half lour, two hours from my first examination, lie was able to recognize a lighted candle as such, but could not distinguish objects, such as a puir of scissors, knife, picture, ets. From this time on his eyesight returned with great rapidity, and three hours after my first examination he was abis to distinguish objects and. people wth great precision. On account of his general condition I did not make any examination of his visual fields at this time. His temperature never went above $09.4 \mathrm{~F}$. At $10 \mathrm{p}$. m. I found his vision normal, pulse 72 , temperature $98.4 \mathrm{~F}$., respirution 18 . At this time I found the Bnbinski reflex on the left hard to elicit but questionably present. The chief symptom at this time was vertigo on motion.

Subsequent Course.-The next day he felt perfectly well except for the vertigo which was present when he was propped up too erectly in his bed. He had an attack of nausen and vomiting at 5 a. $\mathrm{m}$. A careful examination for hemianopsia, astereognosis and lack of sense of position in the limbs proved negative. His reflexes were all normal and the l3abinski reflex on the left was replaced by normal plantar flexion. The recovery was uninterrupted, and four days after the accident he was leading his normal life. There was never any disturbance of bladder or rectal functions. The only therapeutic treatment was magnesium sulphate to open the bowels.

The case is interesting on account of the rapid clearing up of the complete blindness, the sudden causation of the monolateral Babinski reflex, which cleared up within cighteen hours, and the very evident interference with the spinal reflex inhibitory mechanism with no symptoms of compression.

After writing the above report, the Deutsche medizinische Wochenschrift (August 4, 1910) has come to hand, in which is a short paper by Hirsch of Prag ("Ueber passagere Rindenblindheit durch Commotio cercbri"). There is no mention of any examination for involvement of the central nervous system, other than a careful examination of the eye. He cites Wildbrand and Sänger ("Dic Neurologie des Auges") as having collected seven cases of similar nature.

111 South 'Twenty-first Street.

\section{Therapeutics}

\section{GENERAL PRINCIPLES IN THE MANAGEMENT OF DISTASES OF THE HEART}

As has been a number of times stated in these columns, with all our knowledge of physics, of cardiac ability and cardiac disability, of blood pressure, of arteriosclerosis, of myocarditis and cardiac muscle degenerations, with all our better knowledge of physical therapy and of the pharmacologic action of drugs, still there are no defects of mankind that are so many times mismanaged and mistreated as are cardiac defects. They arc mistreated from the very fact that the drugs and mathods used are powerlul for good or bad, and not only may the wrong method be instituted, but too much or too little of the method or treatment may be used.

Sir James Barr, of Liverpool. (British Medical Journal, April 24, 1909) discusses the above subject and especially urges the attempt to prevent the development of serious disease of the heart in various conditions, and especially to prevent that which is due to rheumatism. He states a fact, viz., that though the majority of sudden deaths are due to a cardiac cause, still there are very few chronic diseases so amenable to treatment and so computible with long life and comfort, if judiciously inandled, as are diseases of the heart. 